\title{
Sciendo
}

\section{Social media and politics: the case of Ukraine}

\author{
Alessandra Alberti \\ Link Campus University (Italy) \\ Email: \\ Ludovico De Serio \\ University of Genoa (Italy); \\ Email:ludovico.deserio@gmail.com
}

Doi: $10.2478 /$ gssfj-2020-0006

\begin{abstract}
Nowadays, politics is undergoing several changes, especially because of the growing use of social media from politicians, who are using these virtual platforms as tools to gain more and more consent. Social media are also leading to extreme democratization of politics, making it possible for non-politicians not only to enter the sphere of politics but even to win major competitions, such as presidential elections. To bring an actual and highly illustrative example, in this article the authors go through a deep analysis of the former actor and recently elected prime minister of Ukraine Volodimir Zelenskij and his strategical use of social media compared to the one carried out by his opponents, leading bim to win the presidential elections with an enormous consent.
\end{abstract}

Keywords: Politics, Social media, Ukraine, election campaign, political communication

\section{Introduction}

Nowadays, the Internet has allowed anyone to make free and independent information and has introduced new bottom-up forms of information control. Thanks to its openness and multifaceted nature, the network has given an active role to the third actor of political communication (the voters) previously relegated to a passive and spectatorial role. The birth of social media has reintroduced into the circle of political communication voices that did not exist before or did not have the tools to make themselves heard and influence political decisions. The digital age has therefore increased the potential for political participation by the citiz ens who have no access to the network on the most varied platforms. 


\subsection{Zelensky: from TV to reality}

The President on TV became the President in reality. The history of Volodymyr Zelensky, the newly elected leader of Ukraine, is all here: a comedian who played in a tv-series of enormous success which foresaw with surprising precision what then came out at the polls in reality. Zelensky had no experience in managing public affairs and, perhaps also, for this reason, the Ukrainians have given him an overwhelming consensus, over $73 \%$ compared to the $25 \%$ collected by the outgoing President Petro Poroshenko. The obvious and probably more simplistic analysis of the vote brought to think that this is the result of harsh condemnation of the five years of government. An issue that combined with the strong reaction to corruption rooted in the country and the widespread social unhappiness may explain the so-called "vote of protest". The article intends to outline the media character of Zelensky through an analysis of how the way of doing politics has changed over the years. A shift that necessarily changed also the stereotype of the new politician.

The focus is then set on the electoral campaigns of Zelensky, which, for the very first time, is based only on digital channels. The newly elected President had avoided any direct comparisons with the press and political debates with the other candidates - except for a single meeting with Poroshenko, held a few days before the ballot, at the Olympic stadium in Kyiv. The analysis also wants to highlight the social positioning of Zelensky - through a quantitative comparison between his Facebook and Twitter pages and Poroshenko's ones - and the content shared during his campaign, especially taking into account Zelensky's modalities of approach.

\section{The media profile of Zelenski}

When, in 2019, the comedian and TV producer Volodymyr Zelensky surprisingly announced the decision to advance his candidature challenging the heroine of the orange revolution Yulia Tymoshenko and the outgoing President, Petro Poroshenko, a few people believed that he could have won. After leading polls for weeks and dominating the first round - Sunday, April 21st - Zelensky won the run-off and became the President of Ukraine. He triumphed with a political program based mostly on two aspects: the eradication of corruption and inefficiency and the fight against the lobbies and the oligarchs of every political faith.

The population convinced that to govern properly is a better and inexperienced but honest citizen rather than an experienced and corrupt 
politician, preferred the new face of Zelensky at the command. Born in 1978, graduated in law, son of a professor of cybernetics, Zelensky joined the historical collective comedy with KVN, a first Soviet and then Russian humor tv show.

He then founded his group, Kvartal 95, a production company of TV formats born in 2003 through which he became «monopolist of domestic humor» ${ }^{1}$, positioning himself at the top of the ranking of the most successful showbiz companies in Ukraine.

It is with Kvartal 95 that he gave the assault to Ukrainian television, becoming one of the most famous faces on the small screen. However, the qualitative leap only took place in 2015, when the $1+1$ channel of the oligarch Igor Kolomoisky began broadcasting "Servant of the People", a very popular TV series that narrates the story of a high school history teacher, Vasyl Petrovych Holoborodko (played by Volodymyr Zelensky), who unexpectedly wins the elections to the presidency of Ukraine, after a viral video filmed by one of his students shows him angrily ranting against government corruption in Ukraine; from the show to the reality.

As a matter of fact, something similar happened to the actor in real life. In March 2018, Zelensky founded a party called specifically "Servant of the People" - a name copied and pasted from the show - and after months, on New Year's Eve, he announced his candidacy through one of his shows from the TV screens.

However, there are also some shadows surrounding Zelensky's figure. Many people point out his ambiguous closeness to Igor Kolomoisky, one of the richest Ukrainian oligarchs who also owns the $1+1$ television channel where the program of the Presidential candidate was broadcasted and which, in the days of the elections, launched the third season of Servant of the People. The suspicion is that the entire election campaign of Zelensky was not only financed by Kolomoisky but also conceived by the powerful and controversial oligarch who in 2015 resigned as governor of Dnepropetrovsk precisely because of conflicts with the former president Porošenko, after a claim on different financial irregularities to his name. These suppositions brought to the belief according to which Zelensky would be under the direct control of Kolomoisky, while the oligarch himself was preparing to undermine the power system of President Porošenko, his great enemy. Of course, these were only allegations, always rejected by Volodymyr Zelensky, who declares himself a "man of the people".

${ }^{1}$ Machado A. (2015) “Corruption and Monopolies - An Endemic Problem”, Forbes. 
What is evident in the figure of Zelensky is that his character from fiction became reality through a process of building an image that from script became storytelling, a guided and strategically structured one. When the term "image" is used in political communication, it is always necessary to explain to which aspect of this reality we are referring to. There is a dual

phenomenology of the image: the projected image and the perceived image ${ }^{2}$.

Projected image means the politician's image to be diffused through the media and this is the image that must reach - intact, enhanced or deformed - the defined targets.

The perceived image is instead a subjective mental construct influenced by the projected messages, therefore the mental representation of reality conditioned by the sensory stimuli aroused by the strategy of transmitting the image and filtered by mental schemes.

By analysing the figure of Zelensky, it's possible to affirm that, to a certain degree, in his character, the two phenomena merged. The message of his entire electoral campaign and the projected image of the non-corrupt politician who can give the country a new face reached $73 \%$ of Ukrainians as it wanted to be conveyed by the politician himself. Selfies with his supporters, emotional speeches are consistent with the image of the character: a young comedian with no political experience, apparently far from the stereotypes that characterize the post-Soviet political elites. In this "metapolitical" electoral campaign ${ }^{3}$, the image of Zelensky-comic merges with the Zelenskypolitical thanks to the media positioning he created through the wise use of social networks and effective storytelling.

\footnotetext{
${ }^{2}$ Gianpiero Mazzoleni (2017). La comunicazione politica (3rd ed.). Bologna: Il Mulino.

3 ibidem
} 


\section{New political communication.}

In the late eighties, with the advent of what in the literature was defined as "media challenge" ${ }^{4}$, political communication has changed considerably. The Internet, thanks to its interactive nature, has re-launched direct communication between politicians and vice versa, obviating the communicative asymmetry of the mass media. From this moment the strategic representation of the figure of the politicians on the mass media has become a prerequisite of their presence and the image seems to assume central importance for the self-representation of politicians ${ }^{5}$. A new style of politics emerged, which fundamentally changes both the assumptions and the practices of the political context. ${ }^{6}$ The shift to the new politics has been deeply influenced by the media, and by the politicians who now need to master the media and public relations techniques. This new style of politics is also a consequence of a weakened power of the parties themselves and citizens should now be treated as an audience as much as an electorate - an approach which Zelensky has greatly furthered.

Zelensky's power lies not just in the influence of his media, but in the values he promotes. In Ukraine, television remains the most powerful medium for the population ${ }^{7}$ and is experienced as part of everyday life. The link with the everyday media experiences of the population, and the promotion of the values of entertainment and consumption, has given the former comedian

${ }^{4}$ Cfr. B.W.Lance -R.M.Entman (2001). Mediated Politics: An Introduction, in B.W.LANCE -R.M.ENT-MAN(eds), Mediated Politics.Communication in the Future of Democracy (pp.

1-29) New York: Cambridge University Press, ,.

${ }^{5}$ E.Pozzi (1991). Il corpo malato del leader. Di una breve malattia dell'on. Bettino Craxi. Sociologia e Ricerca Sociale, n.36

${ }^{6}$ RISK CHALLENGES | Mancini P. (2011) "Between Commodification and Lifestyle Politics". Institute for the Study of Journalism, Department of Politics and International Relations, University of Oxford. Reuters

7 Television is the dominant news medium in Ukraine. Almost all Ukrainians (96.8\%) watch TV for news at least weekly, including $95.7 \%$ of Crimeans. Radio and newspapers are each used weekly for news by close to one-third of the population $(36.5 \%$ and $33.8 \%$, respectively). About half of Ukrainians overall (50.9\%) have Internet access in their households, including 56.0\% of Crimeans. About nine in 10 Ukrainians age 15 to 24 $(89.0 \%)$ say they go online for news at least weekly, similar to the proportion of young people who watch TV news that often. Data source: The National Council of Television and Radio Broadcasting. 
powerful support. Zelensky's political power is further bolstered by his character and actions - he has enjoyed playing the parts both of a showman and of someone who is 'ordinary' and who has the same reactions, desires and even the prejudices of the average citizen.

With its messages, values, and view of the world, television interferes continuously with politics and determines its values. A political universe abstracted and separated from television seems to be no longer possible. And when a popular and acclaimed TV series can be translated into reality so easily - this has a lot of power for the median voter that can reflect the figure of the actor into the real world.

Zelensky embodies a new era of politics for Ukraine. A new face, never involved in politics before, somebody closer to the population; rich but not an oligarch and acclaimed by his fan to have revolutionary and not corrupted ideas. The ex-comedian entered the political arena when the level of perceived corruption was high, and its candidature was fresh air for the median voter. The vote for Zelensky may be interpreted as an explicit consensus around the way of life he embodies: a choice that goes beyond the State's interest to support the individual concerns. Ukrainians voted for someone who may improve their lifestyle. He put his images on the political stage through a tv series giving the hope the fiction can become reality ${ }^{8}$.

\section{Virtual campaign}

\subsection{Zelensky's social positioning}

For its electoral campaign, Zelensky took advantage of the cheapest but most effective tool available to a politician in 2019: the web; specifically, social media. The difference between his usage of the tool and the usage that many others had done of the internet lies in the fact that Zelensky used exclusively the Web and refused all confrontations with other candidates, as well as meetings with the press. Zelensky has chosen the web as a "horizontal" communication method in which citizens can actively participate. A virtual space where they can share information but also ask for an opinion.

This completely digital election campaign marks, therefore, a further evolutionary step compared to those of Obama in 2008 and Trump in 2016: a disruptive approach, capable of introducing a new way of doing political

${ }^{8}$ Example of FB post from Zelenski's profile https://www.facebook.com/zelenskiy95/videos/2224356801148017/ 
communication, starting from the quality of the shared contents - with evident storytelling deriving from the experience in the entertainment business - to the use of a new social media platform such as Telegram.

Considering that by now Facebook and Twitter are indispensable tools for the entire ruling class, the use of Telegram made by Zelensky allowed our analysis to explore further in detail one of the new frontiers of political communication: instant messaging. Instant messaging offers several advantages to politicians: very high organic reach ${ }^{9}$ and a more targeted audience. On social networks, we faced a plurality of sources and find ourselves overcrowded with the news. In has been estimated that nowadays we read only $5 \%{ }^{10}$ of what appears on our boards and real visibility comes behind payment to the platforms in question. The situation is different for Telegram and other messaging apps that enjoy a higher level of attention. The use of messaging, as an attempt to create a real and less dispersive and superficial involvement, avoids the phenomenon known on the web as slacktivism ${ }^{11}$.

While TV and newspapers are by definition generalists, social media including messaging apps - offer the opportunity to reach out to specific communities and interact with them directly. Experts talk about the need to perform microtargeting, that is to say, they identify specific niches of users to which strategically proposing a small number of precise sensitive topics defined in advance. Telegram can be a useful tool in this sense since it is based on the presence of those audiences - both private and public - necessary to target exactly the profiles to which submitting contents and to understand the reactions of the public. Essential capacity in this process is the big data analysis because it determines the complexity of a digital strategy.

However, this process only works in the presence of a precise plan and objectives, as well as the presence of valid content to be conveyed. They are actions that require time, but that can only bear fruit if they are carried out with a plan. This is why a politician's social media campaign cannot be casual and there is a precise strategy to follow. In the specific case of Zelensky, the strategy was entrusted to two digital marketing experts: Alexander Kornienko

\footnotetext{
${ }^{9}$ Number of people who come into contact with social content (scope) without paying (organic) figures on advertising.

${ }^{10}$ Data source: Wired.it

11 "Activity that uses the internet to support political or social causes in a way that does not need much effort, for example creating or signing online petitions".

(https://dictionary.cambridge.org/)
} 
and Artem Gagarin - who in the social strategy included also Telegram as an effective hub for the distribution of information for free ${ }^{12}$.

Using Fanpage $\mathrm{Karma}^{13}$ - an online tool for social media analytics and monitoring - was carried out an accurate analysis of the official Facebook and Twitter pages of Zelensky. These two social networks were chosen because they are the most commonly used ones by politicians. Fanpage Karma has allowed providing valuable insights on posting strategies and performance of the social media pages selected. Considering the former President Poroshenko a good communicator and an important competitor of Zelensky during the electoral campaign, the social analysis is based on the comparison between Zelensky's pages - Facebook (@zelenskiy.official.team) and Twitter (@ZelenskyyUa) - and Poroshenko’s ones-Facebook (@petroporoshenko) and Twitter(@poroshenko).

\subsection{Facebook analysis}

The analysis starts by looking at the positioning of Zelensky's pages on Mark Zuckerberg's social media, which is used by $58 \%$ of the Ukrainian population active on social networks ${ }^{14}$. The first element to take into consideration is the dispersion: beyond his personal profile (@ВолодимирЗеленський) with 992K follower, Zelensky has another five pages officially related to him. The pages, all active even months after the end of the elections, presented different contents.

\footnotetext{
${ }^{12}$ Ambiguous the names of his spin doctors online. According to most of the website (e.g.Orwell.it) these are the two in charge of his social media strategy

${ }^{13}$ https://www.fanpagekarma.com/

${ }^{14}$ https://gs.statcounter.com/social-media-stats/all/ukraine
} 


\begin{tabular}{|c|c|c|c|c|}
\hline Profile Facebook & $\begin{array}{l}\text { Creation } \\
\text { date }\end{array}$ & Followers & Type & $\begin{array}{l}\text { Paid } \\
\text { content }\end{array}$ \\
\hline @President.gov.ua ${ }^{15}$ & 22.07 .2013 & 26.6 & Ente pubblico & 0 \\
\hline @,official.zelenskiy & 24.10 .2017 & $107 \mathrm{~K}$ & personaggio politico & 1 \\
\hline azze2019official & 29.12 .2018 & $708 K$ & $\begin{array}{l}\text { Organizzazione } \\
\text { politica }\end{array}$ & 2400 \\
\hline @,ze2019ua & 09.01 .2019 & $26.5 \mathrm{~K}$ & Candidato politico & 0 \\
\hline$@$ z,zelenskiy.official.team & 05.05. 2019 & $6.3 \mathrm{~K}$ & personaggio politico & 0 \\
\hline
\end{tabular}

Table 1. Source: Fanpage Karma

The creation of Zelensky's social profiles follows the course of his candidacy in politics. Except for the official page of the office of the Ukrainian President - institutional page activated since Poroshenko's presidency for institutional communications - the digital team of Zelensky created his official pages as his career evolved: in 2017 they began to outline the political profile of the character, with@official.zelenskiy; in 2018 they created the page of the political organization@ze2019official and then, immediately after launching his election campaign in December 2018, in January of the following year, they set up the page of his 2019 Presidential political candidacy @ze2019ua. Only in May 2019, after he was elected a President, the second page set up as a "political character" type has been created. It's interesting to notice how this electoral campaign targeted only Ukrainian native speakers since all the content posted in the pages (apart from @ President.gov.ua) was written in the Ukrainian language.

Among the five pages taken into consideration, the page@ze2019official has been used as a term of comparison. This is because the aforementioned is the only page that showcases sponsored contents and it is therefore assumed to be the page used as a tool of advertising during the campaign. At the same time, the Facebook page@PetroPoroshenko2019 was chosen as the other term of comparison. A page activated on February 5th, 2019 and which now counts $29.7 \mathrm{~K}$ followers. By the way, Poroshenko owns and uses also the page

\footnotetext{
${ }^{15}$ This page is merged with the one @ze2019official (https://www.facebook.com/ze2019official)
} 
@petro.poroshenko from April 2014 - with 2.5M followers - but with this profile, the two terms of comparison wouldn't have been homogeneous. Despite that, it is to be highlighted that in social networks as in reality, a dating profile preserves its history and followers, and has a larger audience to reach.

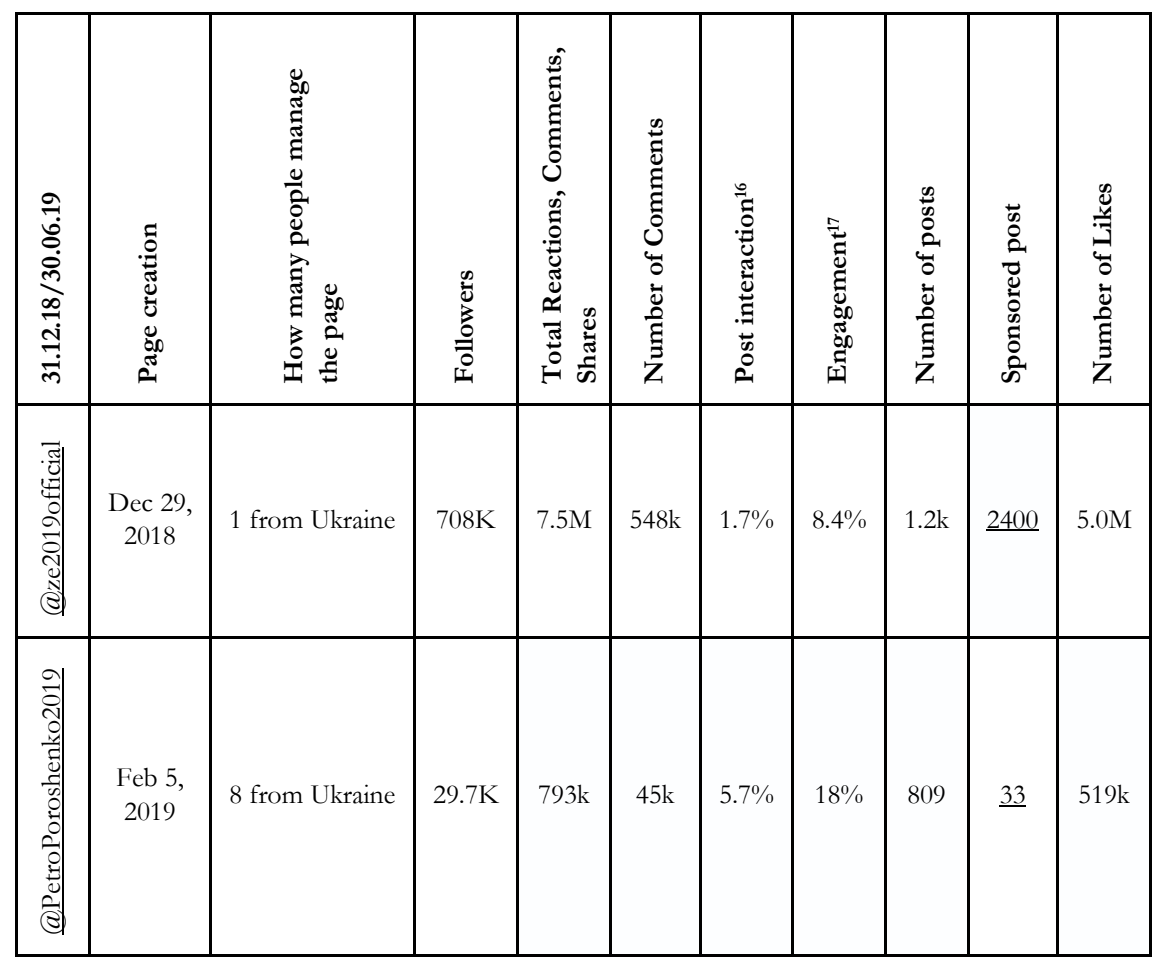

Table 2 Source: Fanpage Karma

First, it is interesting to observe the evolution of these pages. Created nearly in the same period but developing through very different paths: Zelensky, with his media fame as an actor, managed to obtain $708 \mathrm{~K}$ followers - surely thanks to the sponsorship of contents and probably carrying out an aggressive fan acquisition campaign in budget terms - while Poroshenko managed to get less than $30 \mathrm{~K}$. This data is extremely important because a wider audience becomes the key point for increasing the visibility of the contents. Measuring the percentage of the engagement - total fan interaction with a post on the

\footnotetext{
16 The post interaction shows how active the fans engage with a post of a page. It shows the average amount of all interactions (likes, shares, comments) for each fan per post

${ }_{17}$ The Engagement shows an average amount of how often a fan interacts with the posts of a page. It is calculated by dividing the daily number of likes, comments and shares by the number of fans.
} 
total number of fans - could be misleading. Poroshenko has a higher engagement than Zelensky but this is the result of a lower fanbase and therefore of a calculation that foresees a minor denominator and therefore a higher result. In absolute terms, in fact, if we measure the degree of interaction of the posts it results that Zelensky has a much greater impact $-7.5 \mathrm{M}$ of Zelensky against 793K of Poroshenko.

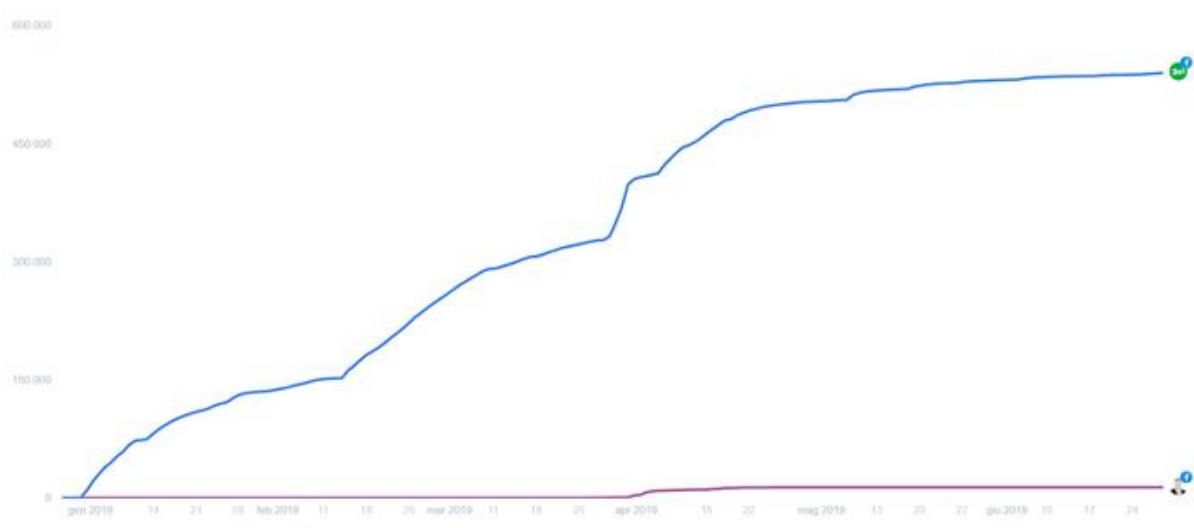

Figure 1. Source: elaborated by Fanpage Karma - Absolute growth of Facebook profiles taken into consideration

Specifically, in absolute terms the interactions during the period 31 December - 30 June were the following: 


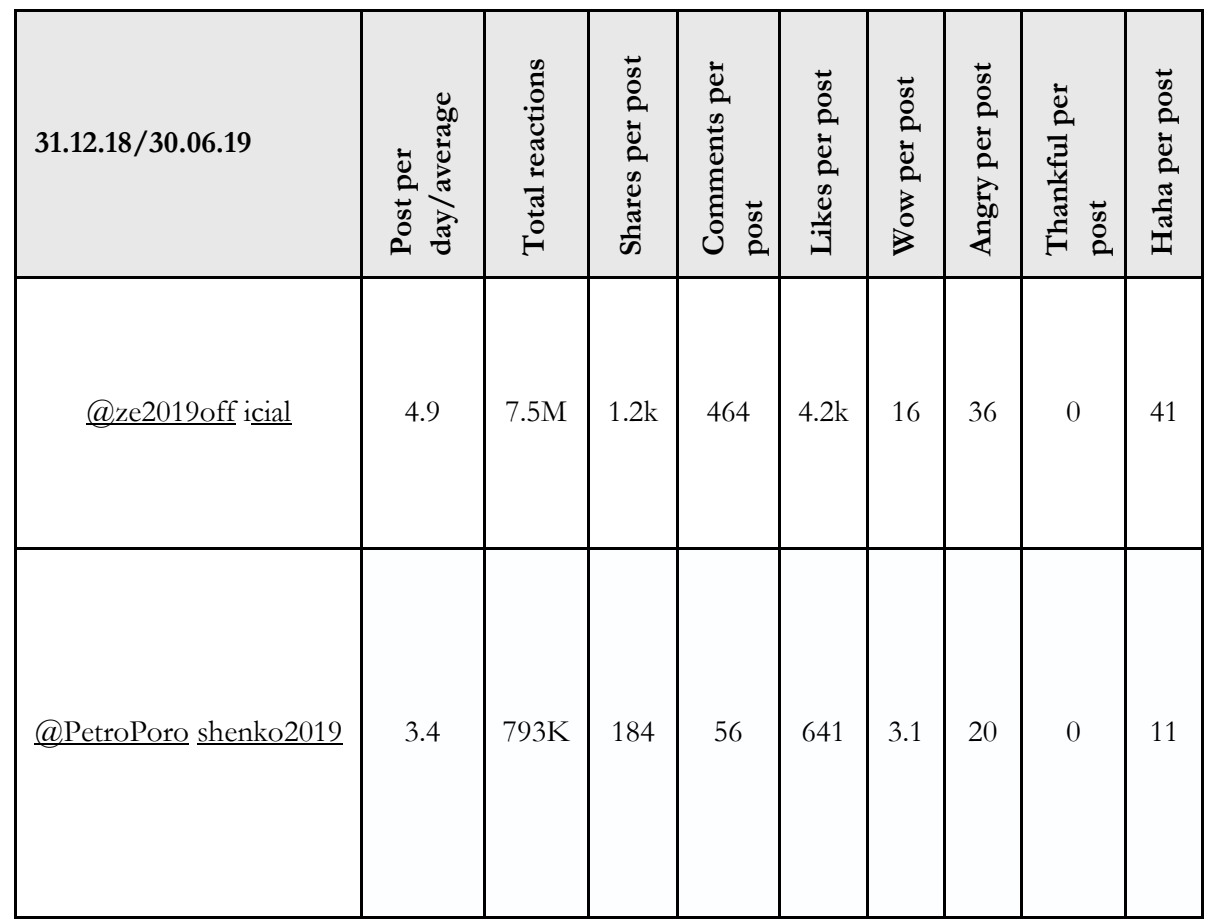

Table 3 Source: Fanpage Karma

The considerably higher value of the interactions on Zelensky's posts demonstrates the success of the interaction that the former comedian managed to establish with his followers. The high number of shares shows appreciation for the content proposed by the Ze team. Sharing content is essential to become viral; in fact, sharing content gives to its creator the possibility to be seen by a different online audience and at the same time it increases the degree of appreciation because the likes on shared posts are added to the original one.

WOW and HAHA reactions, as it is easy to think, are above average in Zelensky's profile, which utilizes a more popular and informal communication style compared to Poroshenko's profile, where communication is more institutional. In absolute terms, therefore, it is clear that Zelensky's Facebook success is striking compared to Poroshenko's. If we consider the 3 best posts in the analysed period of time, we can confirm a clear preference towards Zelensky in absolute terms, and better performance of Poroshenko in percentage terms, given his smaller "fanbase". 


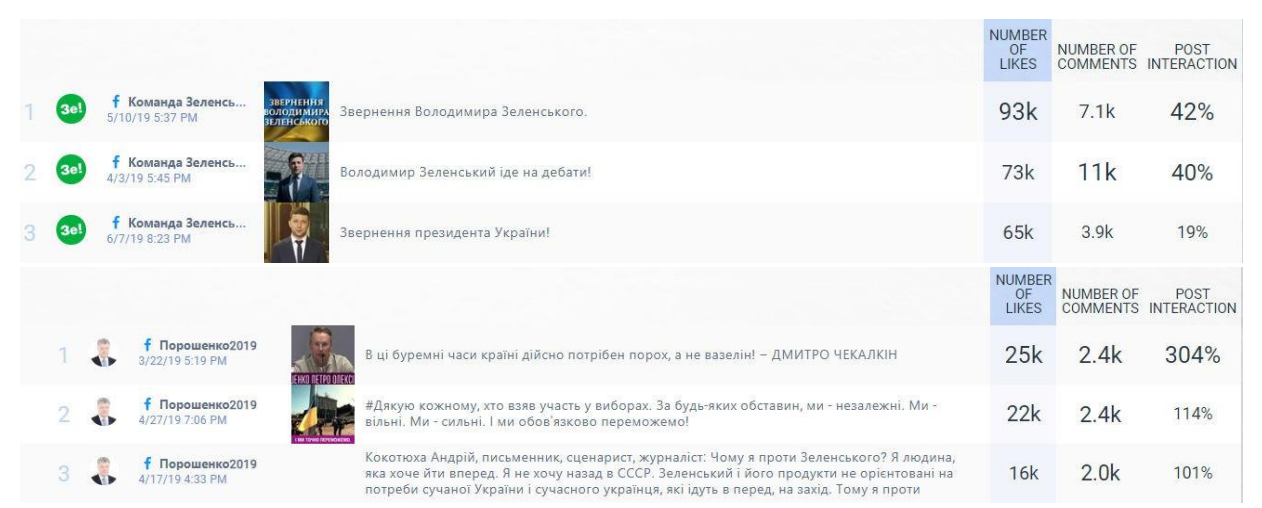

Figure 2. Source

Qualitatively speaking, the analysis shows how Zelensky makes use of a greater amount of pictures and videos, and his language is more popular and close to the average citizen; on the other hand, Poroshenko is more institutional and utilizes words more than images - preferring more consistent post with a great amount of text. A limitation of this analysis is given by the language since it is hard to efficiently take into consideration the formal style using translated content.

\subsection{Twitter analysis}

The first clear difference between the personal accounts of the two leaders (@ВолодимирЗеленський and @Петро Порошенко) is surely constituted by the number of followers. Poroshenko, who opened his twitter profile in April 2014, today counts 1 million and 200K followers, while Zelensky's, which opened only in April 2019, managed to obtain 89K. In this case, the two accounts are the personal profiles of the candidates and the analysis takes into consideration the period range 25.04.19-30.06.19 ${ }^{18}$.

18 This period range was chosen because Zelensky activated his profile in April 2019. 


\begin{tabular}{|c|c|c|c|c|c|c|c|c|}
\hline $\begin{array}{c}\text { Profile } \\
\text { 25.04.19-30.06.19 }\end{array}$ & 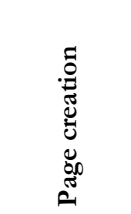 & $\sum_{\tilde{I}}^{\mathscr{E}}$ & 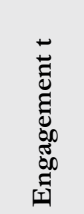 & 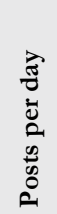 & 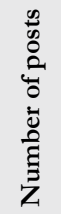 & 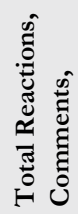 & 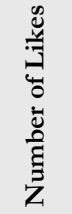 & 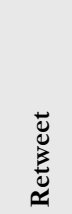 \\
\hline (a)Володимир Земенський & April 2019 & $89 \mathrm{k}$ & $2.3 \%$ & 0.5 & 34 & $107 \mathrm{k}$ & $96 \mathrm{k}$ & $11 \mathrm{~K}$ \\
\hline (а)тро Порошенко & April 2014 & $1.2 \mathrm{M}$ & $0.71 \%$ & 6.5 & 438 & $572 \mathrm{k}$ & $463 \mathrm{k}$ & $108 \mathrm{~K}$ \\
\hline
\end{tabular}

Table 4 Source: Fanpage Karma

Unlike Facebook, on Twitter Zelensky's account records a better engagement than Poroshenko in percentage - and this is due to the lower fanbase but also to greater consistency between the proposed contents and the target of his followers - but not in absolute terms, within which the profile of Poroshenko certainly obtains a far better result.

If for Facebook the use of the two pages was comparable in quantitative terms (post per day), on Twitter the analysis process is different. In fact, in the period considered, the two examined accounts showed a very different rate of publication: 0.5 posts per day for Zelensky versus 6.5 from Poroshenko. It is therefore clear that in the communication strategy of Poroshenko, Twitter played a crucial role, while for Zelensky Facebook remained the mainly used social media. Interesting research provided by Statcounter ${ }^{19}$ and confirmed by Hootsuite $^{20}$, reports that only $5 \%$ (575K users) of the Ukrainian population active on social networks uses Twitter. This means that a high percentage of Poroshenko's followers are probably from abroad. This could explain the positive results of voting from foreign seats favoured the former President in both tournaments.

In terms of the quality of the proposed contents, we can confirm also for Twitter that Poroshenko presented a more text-oriented communication falling within the standards of politicians' ordinary communication on this platform - and with this modality, he finds the best results; while Zelensky in line with his media figure - preferred posting images, and with this approach, he found better feedback.

\footnotetext{
${ }^{19}$ https://gs.statcounter.com/social-media-stats/all/ukraine

${ }^{20}$ Digital 2019 Ukraine (January 2019) v01 LinkedIn SlideShare - p35

(https://www.slideshare.net/DataReportal/digital-2019-ukraine-january-2019-v01)
} 
TOP TEXTS

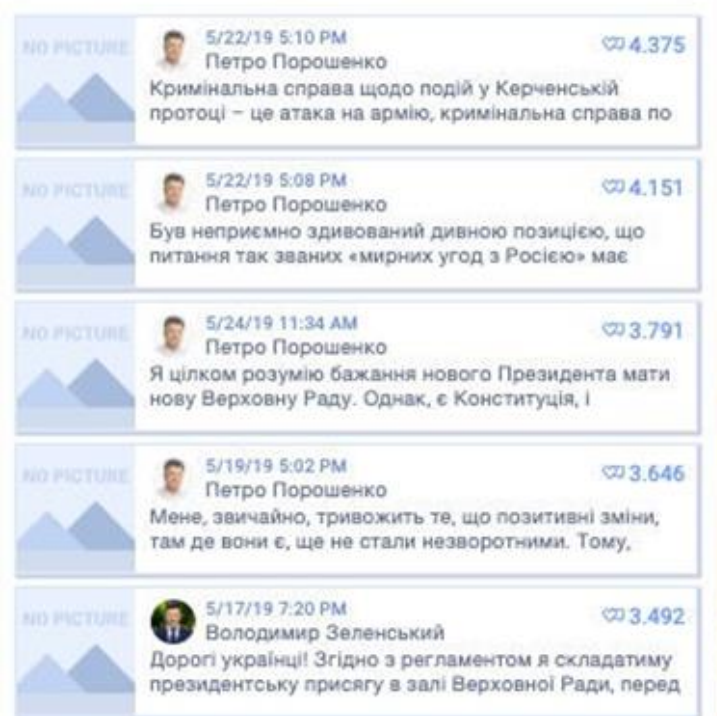

\section{TOP PICS}

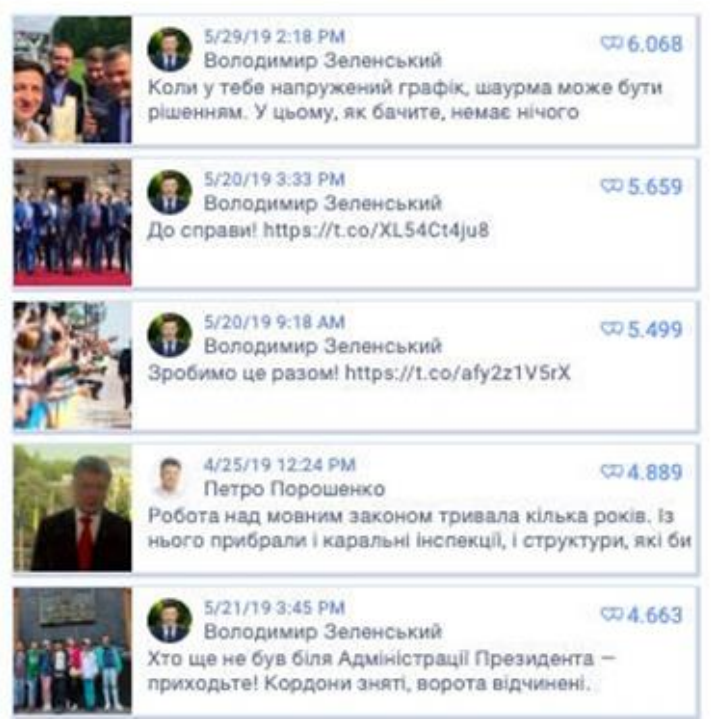

Figure 3. Source

\section{The content of Zelensky's campaign}

Having analysed the methods of communication, comparing those of Zelensky to Poroshenko's ones, the focus is moved to the content of Zelensky's proposals. This analysis starts from the electoral program ${ }^{21}-$ launched on the official website and its social media channels in January 2019 after the candidacy for President released on New Year's Eve - and ends up with the inaugural speech of his Presidency. In general, his approach has three main characteristics:

1. Direct listening of the community: starting from its electoral program, he declared himself open to a confrontation with all citizens. How? Surely through social networks - the ideal medium for enhancing the value of horizontal communication. Zelensky showcases a motivated and compact community of digital followers - a competitive advantage that should not be underestimated for the new President who can speak freely to a wide but specific audience in a single click and collect important feedback. One of the main characteristics of social media is the freedom of expression that

\footnotetext{
${ }^{21}$ Передвиборча програма кандидата на пост Президента України (http://files.ze2019.com/assets/program.pdf)
} 
users feel to have, so that, in addition to strong criticism, constructive feedback can be accumulated and this is helpful to structure an electoral program close to the people's needs.

2. Maintaining a simple and unstructured approach: Zelensky speaks in a language understandable to the whole population - he also speaks both Russian and Ukrainian - he shares his daily life on social networks - from institutional commitments to gym sessions - with such a simplicity that many Ukrainians managed to reflect themselves in his life. Without excesses and luxuries, he arrives on foot the day of the inauguration of his presidency maintaining a low profile to respect the logic of mirroring, that is, "the President is one of us".

3. Incite "the revolution of common sense": an apparent oxymoron that has given continuity to his positioning campaign is the war against the problems always existed in Ukraine - poverty, inequality, and corruption. To eradicate them, the only chance is to vote for somebody out of the box, and the only alternative for breaking the system is Zelensky.

\subsection{Political manifesto}

With 9548 interactions (likes), 13,715 comments and 3640 shares, the political manifesto was officially announced with a Facebook post on January 25th. His message was characterized by a clear and explicit hashtag \# зробимоцеразом (= let's do it together)22. Simple words that contain two clear concepts: the objectives of the program - the need to revolutionize the political class, the need to develop new skills - and the request for collaboration of Ukrainians in shaping the Ukraine of the future23. The text of the post contains the following words:

"Let's present you the long-awaited! Yes, this is it - the election program of the candidate for President of Ukraine Volodymyr Zelensky! The main objective of the program is to bring to power competent and patriotic experts who will embody new ideas and change Ukraine in the direction of digital literacy, comfort, lifelong learning, the openness of power,

\footnotetext{
${ }^{22}$ https://www.president.gov.ua/ru

${ }^{23}$ https://www.facebook.com/404926500265591/posts/420172912074283/
} 
automation of public processes online! The full program is here: https://program.ze2019.com/. Comment, Suggest Your Ideas! This is important because together we will be able to achieve our main goal - to build the Ukraine of our dreams!" \# wewilldoit

Zelensky opened his Electoral Manifesto outlining the Ukraine of his dreams: a country where bureaucratic times will no longer hinder business, where people will find jobs easily and not they must leave the country, where the concerns of young families will become whether to buy a house in the city or in the countryside, where salaries are sufficient to pay bills, where corruption will disappear in favour of fair and equitable actions. It, therefore, touches all the aspirations of the Ukrainian population and then reassures people that all this will be possible in the future. Zelensky then descends into the concrete, explaining how he intends to make all this become a reality. There are 9 values and actions that Zelensky quotes in his electoral program.

1) Let the Ukrainians decide their future through a referendum.

2) Enhance the value of human dignity inside the Ukrainian borders.

3) Justice and equality in front of the law.

4) Human and Country Security, in a country where war is still a reality.

5) Promote honest business for a wealthier state.

6) Zero tolerance for corruption at every level.

7) Starting the Healthy Lifestyle Promotion Program and a life-long learning approach inside the academical sphere.

8) Making Ukraine a comfortable country for young entrepreneurs with an eased taxation system.

9) Providing high-speed internet to everybody.

The manifesto's conclusion reaffirms the need to have new faces with new ideas, somebody who loves Ukraine and want it to change for the better concept that the President himself embodies and expresses from this Manifesto on. Beyond the political Manifesto, which contains the ideals and the main intentions of the politician, another communication line has emerged throughout the study of its social profiles and the official website. Understandably this issue focuses on the foreign policy dossier and specifically the resolution of the conflict and relations with Russia. If his program does not provide for direct negotiations with representatives of Donetsk (DPR) and Lugansk (LPR) popular republics, Zelensky says he is ready to hold direct talks with Putin, including with the involvement of "international partners". The list of promises and possible ministers reinforced the impression among voters that the election of Zelensky could represent a plausible prospect for the beginning of a path of reform, while at the same time making manifest the commitment of the new President in 
favour of the pro-western integration of Ukraine and averting the possibility of a return of Kyiv in the orbit of Moscow. Zelensky has never shown himself "soft" against Russia in his election campaign. He repeatedly stressed his support for the Euromaidan ${ }^{24}$ Revolution and criticized the Russian military aggression in the east, even helping to finance nationalist battalions in the war. Yet, there is no doubt that the element of "novelty" that distinguishes Zelensky, his more moderate positions on topics such as bilingualism and his willingness to deal with Putin made his election a more positive prospect for Moscow than a second term of Poroshenko. Already after a month from his appointment as President on the Zelensky team's Facebook page ${ }^{25}$, a video appeared listing the "twenty results achieved", that could be properly called guidelines of his strategy.

\subsection{Inauguration speech}

The President Volodymyr Zelensky swore on the Constitution and took the office during the solemn ceremony at the Rada on May 20th. The speech uttered by Zelensky can be analysed from two points of view: the form and the content.

Considering the form of his inaugural address following the theories of the American political scientist Murray Edelman ${ }^{26}$, who identifies four types of political discourse, It's possible to state that the neo-elected president used an exhortative language in his inaugural speech.

According to Murray, the exhortative category is the most widespread style in political communication. This category integrates the registers of ideology and rhetoric with the objectives of persuasion and the effects of stability and consensus. Therefore, Zelensky's speech - opting for a popular and persuasive language - fits well into the category. The speech also went, on two occasions, from the Ukrainian language to the Russian one, touching the topic of the war in Donbas.

\footnotetext{
${ }^{24}$ Carroll O. (2019), "Ukraine elections: As comedian Zelensky takes the lead, it's no longer a joke in Russia either", Indipendent, 6/04/2019.https://www.independent.co.uk/news/world/europe/ukraine-electionscomedian-russia-volodymyr-zelensky-propaganda-a8857346.html

${ }^{25}$ https://www.facebook.com/ze2019official/posts/452127465545494?comment id=4522 05542204353\&comment tracking $=\% 7 \mathrm{~B} \% 22 \operatorname{tn}^{2} \% 22 \% 3 \mathrm{~A} \% 22 \mathrm{R} \% 22 \% 7 \mathrm{D}$
}

${ }^{26}$ Murray J. E. (1985). The Symbolic Uses of Politics. Illinois: University of Illinois Press. 
As for the content, the new President has marked a clear distance from his predecessors, opting for an openly critical attitude towards the "old politics", which in the last 28 years has, in his opinion, created the conditions for the prosperity of lawlessness and corruption in the country. In his speech, Zelensky emphasized on several occasions the "collective" character of his victory and addressed the millions of Ukrainians abroad, inviting them to return to start a new season for Ukraine. After stressing that the country has embarked on the path towards Europe, Zelensky said that the first task of his presidency will be the resolution of the conflict in the Donbas, "without any loss of territories". For this reason, in a part of the speech, the new President addressed directly to the members of the army, "both Ukrainian-Russian and Russian-speaking heroes" towards whom the government must observe the utmost respect.

In conclusion, Zelensky said that "the Ukrainians want facts, not words": the new President, as he had already announced declared he wanted to dissolve the Rada and called early elections, inviting the old politicians to make room for new faces ready to "put oneself at the service of the people".

Zelensky finally closed the inauguration speech recalling his work as an actor (Ronald Reagan, his "predecessor" as President-actor, was also quoted by him): "Dear people, in life I tried to do everything to make the Ukrainians smile. In the next five years, I'll do everything I can to keep you from crying."

\section{Conclusions on modern political communication}

Political communication has been the subject of studies since the 1950s when in the USA the need to establish a relationship between politicians and citizens began to emerge through a careful study of the messages concerning politics published in the mass media. The complexity of this subject is given not only by its interdisciplinary character but by intrinsic characteristics such as the content itself of the messages and the different channels used to disseminate them. It is therefore not surprising that scholars in this field struggle to find a precise and unanimous definition of the subject, but we know that it has been investigated and analysed by the main disciplines of social science: sociology, social psychology, anthropology, semiotics, and political science. According to the peculiarities of the analysed context, one approach is preferred over another, to emphasize a phenomenon and observe its effects.

It is now clear that over the years all the mass media have shown that they can influence public opinion through instruments such as newspapers, radio, and television. 
Nowadays, however, politics has moved almost completely to the web and, as analysed in this article, more massive and effective use of social media results in greater political success. The media space, in fact, remains firmly in the hands of politicians who base their personal brand on viscerality and emotion: the kind of personality that serves to capture the attention of millions of potential voters glued to their smartphones. Social networks have in fact transformed the political scene into a perennial election campaign.

The American writer, literary critic and sociologist Howard Rheingold, who was the first to use the term virtual communities in the framework of his studies, has always supported the process of shifting politics from traditional mass media to the web, stating that "The political significance of computermediated communication lies in its capacity to challenge the existing political hierarchy's monopoly on powerful communications media, and perhaps thus revitalize citizen-based democracy ${ }^{27 "}$.

While a more direct relationship with the public is indeed formed, it is also true that no critical mediation and no confrontation is allowed on the web regarding the message conveyed by politicians. It is a communication built with bursts of strongly oriented messages, black or white, strictly without shades of grey, tailored to be shared and go viral. The result is an extremely polarized message that is amplified: politicians on social media tend to create actual factions, friends, and enemies. The followers, or rather the fans, end up giving voice to comments more similar to football cheers than to the manifestation of an opinion.

Within the international panorama, the number of cases in which the success and popularity of political candidates are directly proportional to the use of social media and the number of followers is growing: from American President Donald Trump (who invested 1\% spent by contender Jeb Bush, who spent $\$ 28.9$ million on television commercials ${ }^{28}$ ), to French President Emmanuel Macron (the most followed European leader on twitter, with over 4 million followers) to former Italian Interior Minister Matteo Salvini (the

\footnotetext{
27 Andrejevic, Mark (2013). "Public Service Media Utilities: Rethinking Search Engines and Social Networking as Public Goods". Media International Australia. 146 (1): 123-132

${ }^{28}$ Murray M. (2015), \$47.5 Million Can’t Buy These Candidates Love (At Least So Far), NBC News, 01/12/2015.
}

https://www.nbcnews.com/politics/2016-election/47-5-million-cant-buy-these-candidateslove-least-so-n472166 
politician with the highest number of followers in Italy and one of the highest in Europe), to the recently re-elected Israeli Prime Minister Netanyahu (with over a million followers on twitter), to Romanian Prime Minister Klaus Iohannis and Brazilian President Jair Bolsonaro, who both managed to capitalize on a growing consensus on social issues by triumphing in the elections in their respective countries.

If it is true that the shift of political action on social media represents growing democratization, the side effect seems to be that politics no longer requires training, experience, culture. In the new politics, vote aside, the number one indicator has returned to be the "thumbs up" of ancient Rome and every "like" missing represents a missed vote. So political strategies are transformed into marketing strategies and in the same way, a product must be attractive to the public to be bought, so a politician must be liked by the public to be voted. This strategy profoundly transforms politics, which goes from the noble art of governing to achieve the common good to the "not noble art" of selling an online image.

\section{References}

Andrejevic, M, (2013). "Public Service Media Utilities: Rethinking Search Engines and Social Networking as Public Goods", Media International Australia.146 (1): 123-132

Carroll O. (2019), "Ukraine elections: As comedian Zelensky takes the lead, it's no longer a joke in Russia either”, Indipendent, 6/04/2019.

Lance B.W., Entman R.M. (2001). Mediated Politics: An Introduction, in B.W.Lance, R.M. Ent-man (eds), Mediated Politics.Communication in the Future of Democracy ,New York, Cambridge University Press, pp. 1-29.

Machado A. (2015). "Corruption and Monopolies - An Endemic Problem”, Forbes.

Mancini P. (2011) "Between Commodification and Lifestyle Politics". Institute for the Study of Journalism, Department of Politics and International Relations, University of Oxford. Reuters.

Mazzoleni G. (2017). La comunicazione politica (3rd ed.). Bologna: Il Mulino.

Murray J. E. (1985). The Symbolic Uses of Politics. Illinois, University of Illinois Press.

Pozzi E. (1991). Il corpo malato del leader. Di una breve malattia dell'on. Bettino Craxi. Sociologia e Ricerca Sociale, n.36.

Murray M. (2015), \$47.5 Million Can’t Buy These Candidates Love (At Least So Far), NBC News, $01 / 12 / 2015$ 
Geopolitical, Social Security and Freedom Journal, Volume 3 Issue 1, 2020

\section{Web References}

The National Council of Television and Radio Broadcasting: https://www.nrada.gov.ua/en/ Zelenski's facebook profile: https://www.facebook.com/zelenskiy95/videos/2224356801148017/

Cambridge Dictionary: https://dictionary.cambridge.org/

Wired Italia: Wired.it

Fanpage Karma: https://www.fanpagekarma.com/

Social Media Stats Ukraine, Statcounter: https://gs.statcounter.com/social-mediastats/all/ukraine

Digital 2019 Ukraine (January 2019) v01 LinkedIn SlideShare (https://www.slideshare.net/DataReportal/digital-2019-ukraine-january-2019-v01)

Передвиборча програма кандидата на пост Президента України (http:// files.ze2019.com/assets/program.pdf)

Zelensky's team facebook page Команаа Зеленського: https://www.facebook.com/ze2019official/posts / 452127465545494?comment id=452205542204353\&comment tracking $=\% 7 \mathrm{~B} \% 22 \mathrm{tn} \% 22 \% 3 \mathrm{~A} \% 22 \mathrm{R} \% 22 \% 7 \mathrm{D}$ 